\title{
Heavy Metal and Phosphorus Removal from Waters by Optimizing Use of Calcium Hydroxide and Risk Assessment
}

\author{
Binyuan Chen \\ Department of Environmental and Safety Engineering \\ Changzhou University \\ 1 Ge Hu Road, Changzhou 213164, Jiangsu, China

\begin{abstract}
Ruijuan Qu, Jiaqi Shi, Dinglong Li, Zhongbo Wei, Xi Yang \& Zunyao Wang (Corresponding author)
State Key Laboratory of Pollution Control and Resources Reuse

School of Environment, Nanjing University

163 Xian Lin Street, Nanjing 210046, Jiangsu, China

Tel: 86-25-8968-0358Ｅ-mail: wangzunyao315cn@163.com
\end{abstract}

Received: November 18, $2011 \quad$ Accepted: November 29, $2011 \quad$ Published: January 1, 2012

doi:10.5539/ep.v1n1p38

URL: http://dx.doi.org/10.5539/ep.v1n1p38

The research was financially supported by the National Natural Science Foundation of China (41071319, 20977046, 20737001) and the Fundamental Research Funds for the Central Universities of China (1112021101)

\begin{abstract}
The optimizing using calcium hydroxide to remove dissolved heavy metal, phosphorus pollutants and algae was investigated. It was found that the concentration of calcium ion was minimal at $\mathrm{pH} 10.5$ when a large amount of generated calcium carbonate increased the particle size of the precipitates and improved sedimentation of sludge and the removal efficiency of heavy metal and phosphorus significantly. Regardless of the initial heavy metals concentrations contained in the wastewater, the final treated concentrations were all extremely low. Risk assessment in alkaline environment of $\mathrm{pH} 10.5$ was tested by fancy carp, daphnia, seed, luminescent bacterium Q67. The results showed that $\mathrm{pH} 10.5$ had a little influence on the four tested organisms. Thus it is suggested that calcium hydroxide at $\mathrm{pH} 10.5$ may be a potential method for treating wastewater and eutrophication water.
\end{abstract}

Keywords: Heavy metals, Phosphorus, Co-precipitation, Calcium hydroxide, Risk assessment

\section{Introduction}

Heavy metals-containing human, industrial and urban wastewaters, which were discharged into river systems, caused a serious problem that is a major concern worldwide (Tsai, Yu, Chen, \& Kung, 2003). Heavy metals are harmful to both human and aquatic life (Stéphanie Lecomte \& Ehrhardt, 2001). They are present in soluble form in the aqueous solution over a wide range of $\mathrm{pH}$ values and quite mobile in the natural environment (Baek \& Yang, 2004). When wastewater containing higher concentration of heavy metals is discharged into the natural water bodies, it affects aquatic life and is destructive to the environment. Even trace amounts of heavy metal pollution, can produce bioaccumulation through the food chain. When people drink the water or eat the food contaminated by heavy metals, there will be high contents of heavy metals in the body, leading to a variety of incurable diseases.

Lead is a recognized environmental pollutant that acts as a cumulative poison. Inorganic $\mathrm{Pb}^{2+}$ is an enzyme inhibitor, which affects the nervous system. Once being mobile in the environment in the ionic form, it finds its way into the human body through drinking water, food and air, like many other toxic elements (Bhattacharjee, Chakrabarty, Maity, Thakur, \& Bhattacharyya, 2003). As a trace element, zinc is essential for human health. It is important for the physiological functions of living tissues and regulates many biochemical processes. However, too much zinc can cause eminent health problems, such as stomach cramps, skin irritations, vomiting, nausea 
and anemia (Oyaro, Oyaro, Juddy, Murago, \& Gitonga, 2007). Copper plays an important role in animal metabolism. But the excessive ingestion of copper brings about serious toxicological concerns, such as vomiting, cramps, convulsions, or even death (Paulino, Minasse, Guilherme, Reis, Muniz, \& Nozaki, 2006). Exceeding its critical level, nickel might cause serious lung and kidney problems, besides gastrointestinal distress, pulmonary fibrosis and skin dermatitis (Borba, Guirardello, Silva, Veit, \& Tavares, 2006). And it is known that nickel is a human carcinogen. Cadmium has been classified by the U.S. Environmental Protection Agency as a probable human carcinogen. Cadmium exposure will create severe risks to human health. Chronic exposure of cadmium can result in kidney dysfunction and high levels of exposure will result in death (Fu \& Wang, 2011).

In some developing countries, drinking water resources are threatened by harmful algae blooms (HABs) (Chen, He, Huang, Kong, Lin, Li, \& Zeng, 2009a). It is evident that nitrogen (N) and phosphorus (P) contained in agricultural effluents and industrial wastewaters are mainly responsible for eutrophication Smith, Tilman, \& Nekola, 1999) and it is necessary to reduce both $\mathrm{N}$ and $\mathrm{P}$ inputs for long-term eutrophication and cyanobacterial bloom control in hyper-eutrophic system (Paerl, Xu, McCarthy, Zhu, Qin, Li, \& Gardner, 2011). Controlling aquatic nutrients especially phosphorus was emphasized as the chief measure to conquer HABs (Martin \& Katrin, 2000).

To remove heavy metals, many techniques including ion exchange with a material possessing ion exchange capability, membrane filtration, reverse osmosis, and electrodialysis, etc. have been used. Meanwhile, various measures, including ultrasonic radiation, dissolved air flotation, chlorine or permanganate oxidation, have been adopted to remove algae. However, combined with the complicated operation process, the extremely high expenses of source control made these methods would not become highly effective until 10 years later or even longer.

By far, chemical precipitation is an effective and the most widely used process in industry, because it is relatively simple and inexpensive to operate (Ku \& Jung, 2001). In the precipitation processes, chemicals react with heavy metal ions to form insoluble precipitates. The forming precipitates can be separated from the water by sedimentation or filtration. And the treated water is then decanted and appropriately discharged or reused. The most extensively employed chemical precipitation technique is hydroxide precipitation due to its relative simplicity, low cost and ease of $\mathrm{pH}$ (Huisman, Schouten, \& Schultz, 2006). Calcium hydroxide is an ideal precipitation agent because of the low cost of fabricating and high processing effects. But the precipitates of amphoteric metals, for example, zinc and lead, tend to re-dissolve as the $\mathrm{pH}$ changes beyond the optimal range. Consequently, $\mathrm{pH}$ must be controlled strictly.

In this study, sodium hydroxide and calcium hydroxide were used to adjust the $\mathrm{pH}$. The objective of this work was to optimize the control condition in which the most important was the value of $\mathrm{pH}$ to remove heavy metals from solutions. The agglomeration of the precipitates during the treatment was investigated and characterized by scanning electron microscope (SEM). The additional experiment was carried out for removing the algae and $\mathrm{P}$ under the natural aerate-scale condition, as a part of this investigation, the degree to which the four aquatic organisms-fancy carp, daphnia, seed, Luminescent bacterium $Q 67$ were affected when living in the treated water with $\mathrm{pH} 10.5$ was investigated.

\section{Materials and Methods}

\subsection{Materials}

All primary chemicals used were of analytical grade. Solutions (synthetic effluents) containing zinc, copper, manganese, nickel, lead, cadmium and di-hydrogen phosphate were prepared by dissolving the metals in deionized water at a concentration of $500 \mathrm{mg} / \mathrm{L}$ for precipitation studies.

\subsection{Precipitation}

\subsubsection{Synthetic Wastewater}

Samples for removal experiment of heavy metals and phosphate were taken randomly at three different time points. These samples were tested with the Jar test. In the Jar test, sodium hydroxide and calcium hydroxide were separately added to the samples to adjust the $\mathrm{pH}$ to different values. The $\mathrm{pH}$ was constantly monitored using a METTLER TOLEDO S20P-K pH meter with a glass electrode. In the process, the samples were stirred at 350 $\mathrm{r} / \mathrm{min}$ with magnetic stirring apparatus. $15 \mathrm{~mL}$ of the samples were taken at every $\mathrm{pH}$ point with a pipette. Then, keeping the water samples static and the supernatants taken at a constant depth of $30 \mathrm{~mm}$ using the pipette from each vessel were collected. Then, a certain volume of each water sample was acidified by adding nitric acid. The concentration of $\mathrm{Cd}^{2+}$ was measured using graphite furnace atomic absorption spectrometry (AA-600, Perkin-elmer, USA). The concentrations of $\mathrm{Cu}^{2+}, \mathrm{Pb}^{2+}, \mathrm{Zn}^{2+}, \mathrm{Mn}^{2+}, \mathrm{Ni}^{2+}, \mathrm{Cd}^{2+}$ and $\mathrm{P}$ were determined using 
atomic emission spectrometry (ICP) (J-A1100, Jarrell-Ash, USA). The concentrations of heavy metal ions and P were measured, and how $\mathrm{pH}$ values affect the treatment effectiveness was investigated.

After calcium hydroxide was mixed with the synthetic heavy metal-containing wastewater under stirring at $\mathrm{pH}$ 10.5, the suspending substance precipitated in $30 \mathrm{~min}$ and was then washed with deionized water thoroughly. The sediments were characterized using SEM (S-3400N II, Hitachi, JP) micrograph analysis.

\subsubsection{River Water}

The water sample used was taken from the river in the Nanjing University. Different dosages of calcium hydroxide were added to adjust $\mathrm{pH}$ to $9.0,10.0,10.5,11.0,11.5$. The concentrations of total phosphorus (TP), total dissolved phosphorus (TDP) and chlorophyll a in the treated water samples were measured.

After digesting the water sample with $\mathrm{H}_{2} \mathrm{SO}_{4}-\mathrm{HClO}_{4}$ directly, the TP contents were determined. The TDP contents were determined by filtrating the water samples through a $0.45 \mu \mathrm{m}$ membrane and then digesting the filtrate. The analysis method was both the molybdenum-antimony anti-spectrophotometric method (Murphy \& Riley, 1962). The difference of TP and TDP was the concentration of particulate phosphorus (PP). Extracted with $90 \%$ ethanol, the concentration of chlorophyll a was determined spectrophometrically (ISO, 1992). The specific procedure is as follows: $500 \mathrm{~mL}$ of the samples were filtered through a $0.45 \mu \mathrm{m}$ Whatman $\mathrm{GF} / \mathrm{C}$ filter and chlorophyll a was extracted with $90 \%$ ethanol at $80{ }^{\circ} \mathrm{C}$ for $5 \mathrm{~min}$. After filtration of the extract, $10 \mathrm{~mL}$ of the filtrate was taken for acidification by $10 \mathrm{uL}$ of $3 \mathrm{~mol} / \mathrm{L}$ hydrochloric acid. The absorbances of the two filtrates were measured at $665 \mathrm{~nm}$ and $750 \mathrm{~nm}$.

\subsection{Bio-toxicity Detection of the Treated Water and Toxicity Test}

\subsubsection{Fancy Carp}

The experimental fish, fancy carp were obtained from a fish hatchery in Nanjing. The fish were fed for 15 days in an aquarium, with an average weight of $50 \pm 8 \mathrm{~g}$ and length of $12 \pm 1 \mathrm{~cm}$. Then fish were transferred to 3 glass aquaria (18 individuals/ aquarium) with $200 \mathrm{~L}$ of freshwater via a continuous system of water filtration and aeration. Temperature was maintained at $21 \pm 2{ }^{\circ} \mathrm{C}$ and dissolved oxygen values at $7.0 \pm 0.5 \mathrm{mg} / \mathrm{L}$. Mean values for additional parameters of water quality were: $\mathrm{pH} 7.8 \pm 0.2$, conductivity $305 \mu \mathrm{S} / \mathrm{cm}, \mathrm{Ca}^{2+} 0.6 \mathrm{mmol} / \mathrm{L}$ and $\mathrm{Mg}^{2+} 0.3 \mathrm{mmol} / \mathrm{L}$.

Fish treatment groups consisted of control group (aquarium 1), the group exposed to the constant $\mathrm{pH}$ value 10.5 (aquarium 2) and the group of the initial pH 10.5 under natural aeration (aquarium 3). All experimental fish were fed once a day and the exposure solutions were completely not changed. Calcium hydroxide emulsion was used to adjust the $\mathrm{pH}$ value of water to 10.5 . The $\mathrm{pH}$ of the water in aquaria 2 was controlled every day to keep the $\mathrm{pH}$ value stable, and the control condition of aquarium 3 were kept the same as that of the control group. The fish were sampled on the days $0.5,1,2,4,8,12$, and antioxidant enzymatic activities (SOD), lipid peroxidation (MDA) and catalase (CAT) were measured.

All tests of bio-marks were conducted the day after the preparation of tissues. According to results from the preliminary experiments, we chose $0.9 \% \mathrm{NaCl}$ solution as the dilution. Liver samples were homogenized with ice-cold $0.9 \% \mathrm{NaCl}$ and then centrifuged at $4000 \mathrm{r} / \mathrm{min}$ at $4{ }^{\circ} \mathrm{C}$ for $17 \mathrm{~min}$. The resulting supernatants were used for the determination of SOD, MDA and CAT levels.

The activities of SOD, MDA and CAT were measured using the Diagnostic Reagent Kit, purchased from Nanjing Jiancheng Bioengineering Instuitute (Jiancheng, China), according to the manufacturer's instructions.

\subsubsection{Daphnia}

Daphnia, originally isolated from Lake Taihu, in the city of Wuxi, were maintained in parthenogenetic cultures in our laboratory. The cultures were acclimated at $25 \pm 1{ }^{\circ} \mathrm{C}$ under a $14 \mathrm{~h}$ light $/ 10 \mathrm{~h}$ dark cycle before the experiment. $\mathrm{EC}_{50}$ values for daphnia exposed to the alkaline environment were determined according to ISO method (ISO 6341, 1996). For each treatment, ten daphnia aged 6-24 h were placed in $150 \mathrm{~mL}$ glass beakers containing $100 \mathrm{~mL}$ of exposure solutions. All the groups were set to four parallel tests and repeated twice. The daphnia were not fed during the test.

\subsubsection{Seed Germination}

In this part, the toxic effects of alkalinity on Huaxing early V Chinese cabbage were assessed, based on seed germination. The mature, full seeds with similar sizes were chosen and sown in the glass culture dishes. 15 seeds contained in the rolled filter paper with $5 \mathrm{~mL}$ of respective test solutions are cultivated in each dish. The seeds cultured in distilled water were served as a control. The germination test was conducted under the condition of darkness with a temperature of $25 \pm 1{ }^{\circ} \mathrm{C}$ in the culturing box (SPX-250, Fuma, China). The number of 
germinated seeds was counted three days later. All the treatments were replicated 3 times in order to minimize experimental error. A seed was considered to be germinated when the emerging radicle elongated to $2 \mathrm{~mm}$.

\subsubsection{Luminescent Bacterium Q67}

Freshwater Photobacterium phosphoreum $Q 67$ were provided by the Biology Department of the East China Normal University (ECNU). The cultured slant was diluted with distilled water in proper amount (luminous density of the blank control tube was controlled within the measurement range of the luminescence apparatus). The testing medium was composed of distilled water and a certain amount of calcium hydroxide and the blank solution was $2 \mathrm{ml}$ of distilled water. Before each test, the relative light unit (RLU) of Q67 suspension was adjusted to around $50 \%$ by adding test mediums to let determined concentration be in the appropriate range. Three parallel samples were taken for each concentration group with $2.0 \mathrm{~mL}$ in the colorimetric tubes, and $2 \mathrm{~mL}$ of distilled water was set as the blank control group. The assays of $Q 67$ were carried out by adding $0.5 \mathrm{~mL}$ of bacterial suspension and $2.0 \mathrm{~mL}$ of test medium to a colorimetric tube. The mixture was thoroughly mixed and the RLU was recorded by a luminometer (BHP9511, Binsong Photonics, China). The final RLU was recorded after 15 min incubation at $22 \pm 1{ }^{\circ} \mathrm{C}$.

\section{Results and Discussion}

\subsection{Golden Point}

Initial treatment runs was added calcium hydroxide solution in the river water which never joined any other heavy metals. The $\mathrm{pH}$ of river water was adjusted stable to $7.9,8.4,8.9,9.4,9.9,10.5,10.8$, and 11.3, respectively. Figure 1 showed that the calcium concentration increased mildly at first, and then dropped slowly until the $\mathrm{pH}$ value was 10.5. After this Golden point, the concentration of calcium increased obviously. The lowest concentration of calcium in the solutions during the process was $24.83 \mathrm{mg} / \mathrm{L}$, a half of the initial concentration. It is possible that abundant carbonate ions exist in the water when calcium hydroxide was added in:

$$
\mathrm{Ca}(\mathrm{OH})_{2}+\mathrm{CO}_{2} \rightarrow \mathrm{CaCO}_{3} \downarrow+\mathrm{H}_{2} \mathrm{O}
$$

There were generating a large amount of calcium carbonate, with no need to add sodium carbonate or aerate carbon dioxide into the water.

During the experiment, we also recorded the conductivity, which presented the similar variation to the calcium concentration. The reduction of the ion content at $\mathrm{pH} 10.5$ brought about the decrease of the conductivity. There is no question that the point of $\mathrm{pH}$ value 10.5 is very significant. Though the turbidity of the solution was very high due to the generated large amount of calcium carbonate, the suspensions were soon settled down after 30 min. All the evidence suggested that the golden point is worth to research.

\subsection{Heavy Metal Removals}

Chemical precipitation is widely used for heavy metal removal from inorganic effluent. After the $\mathrm{pH}$ is adjusted to the basic condition ( $\mathrm{pH}$ 10.5), the dissolved metal ions are converted to the insoluble solid phase via a chemical reaction with a precipitant agent. Usually, the precipitation will be suspended in the water. Therefore, the remove effect is not satisfactory.

The results of the precipitation experiments are shown in Table 1. It was found that the optimum $\mathrm{pH}$ for chemical coagulation and precipitation by sodium hydroxide and calcium hydroxide were larger than 10.5 , at which point the $\mathrm{Zn}^{2+}, \mathrm{Mn}^{2+}, \mathrm{Cd}^{2+}, \mathrm{Ni}^{2+}, \mathrm{Pb}^{2+}, \mathrm{Cu}^{2+}$ levels in the micro-polluted water could be decreased significantly. The mechanism of heavy metal removal by chemical precipitation is presented in Eq. (2) (Wang, Vaccari, Li, \& Shammas, 2005):

$$
\mathrm{M}^{2+}+2 \mathrm{OH}^{-} \rightarrow \mathrm{M}(\mathrm{OH})_{2} \downarrow
$$

Where $\mathrm{M}^{2+}$ and $\mathrm{OH}^{-}$represent the dissolved metal ions and the precipitant, respectively, while $\mathrm{M}(\mathrm{OH})_{2}$ is the insoluble metal hydroxide.

The testing revealed that calcium hydroxide could be successfully removed from the synthetic water by the formation of calcium carbonate at the golden point. The removal efficiencies showed that the treatment effect was strongly dependent upon $\mathrm{pH}$, and $\mathrm{pH}$ value 10.5 was the optimal control point. In the $\mathrm{pH}$ region above 10.5 , the removal rate of $\mathrm{Mn}^{2+}$ almost reached to $100 \%, \mathrm{Cd}^{2+}, \mathrm{Zn}^{2+}, \mathrm{Ni}^{2+}, \mathrm{Cu}^{2+}$ and $\mathrm{Pb}^{2+}$ were respectively $96.48 \%$, $99.76 \%, 86.74 \%, 96.76 \%$ and $89.67 \%$ precipitated, and the residual concentration satisfied the following provision stipulated in Limits Environmental Quality Standards for Surface Water of China: Mn $0.1 \mathrm{mg} / \mathrm{L}, \mathrm{Cd}$ $0.005 \mathrm{mg} / \mathrm{L}, \mathrm{Zn} 0.05 \mathrm{mg} / \mathrm{L}, \mathrm{Cu} 1.0 \mathrm{mg} / \mathrm{L}$ and met the discharge limit stipulated in The Integrated Wastewater Discharge Standard of China for $\mathrm{Ni}^{2+} 1.0 \mathrm{mg} / \mathrm{L}$. Improving the $\mathrm{pH}$ value, the $\mathrm{Cd}^{2+}, \mathrm{Mn}^{2+}, \mathrm{Ni}^{2+}$ and $\mathrm{Cu}^{2+}$ 
concentrations reduced further while the concentration of $\mathrm{Pb}^{2+}$ decreased. The amphoteric heavy metals tend to re-dissolve as the $\mathrm{pH}$ changes beyond the optimal range. The mass of calcium carbonate reduced the re-dissolution degree of $\mathrm{Pb}^{2+}$ into the solution.

It can be seen that the removal efficiency of calcium hydroxide was better than that of sodium hydroxide except for $\mathrm{Zn}^{2+}$. The initial concentrations of $\mathrm{Zn}^{2+}$ in the sodium hydroxide group were all lower than those in the calcium hydroxide group and the remove efficiency of $\mathrm{Zn}^{2+}$ by these two reagents was all $99.76 \%$. What's more, the deficiency of sodium hydroxide was the higher cost than calcium hydroxide.

Then we used calcium hydroxide to treat the heavy metal of the higher concentration in the synthetic wastewater (Table 2). The results indicated that the concentration of the six heavy metals all dropped a lot with the removal efficiency more than $95 \%$. We controlled the $\mathrm{pH}$ value to 6-11, the residual concentrations of copper reduced to $0.948 \mathrm{mg} / \mathrm{L}, 0.748 \mathrm{mg} / \mathrm{L}, 0.066 \mathrm{mg} / \mathrm{L}$ and $0.085 \mathrm{mg} / \mathrm{L}$ when the initial concentration was $150 \mathrm{mg} / \mathrm{L}, 40 \mathrm{mg} / \mathrm{L}, 10$ $\mathrm{mg} / \mathrm{L}$ and $2.3 \mathrm{mg} / \mathrm{L}$, respectively (Figure 2). It is suggested that calcium hydroxide has a strong ability to remove the heavy metals in wastewater.

The effect of the treatment may depend on calcium carbonate as precipitant/ flocculant during the process, improve the removal effect. During the coagulation/flocculation a part of the calcium ions precipitated as calcium carbonate. These precipitates form an important part of the produced flocs. The amount of calcium carbonate precipitated may influence the concentration of heavy metals in the effluent. Calcium hydroxide is better used in complex wastewater than simulated single-metal wastewater because a lot of precipitates are generated during the treatment process of complex wastewater. As a seed material, various sediments including calcium carbonate make the heavy metal ions co-precipitated.

Calcium hydroxide also excellently removed most of heavy metals in the electroplating wastewater. The results have been summarized in Figure 3. The concentration of $\mathrm{Ni}^{2+}, \mathrm{Zn}^{2+}, \mathrm{Cu}^{2+}$ and $\mathrm{Mn}^{2+}$ in the untreated wastewater were $198.55 \mathrm{mg} / \mathrm{L}, 13.69 \mathrm{mg} / \mathrm{L}, 116.54 \mathrm{mg} / \mathrm{L}$ and $0.68 \mathrm{mg} / \mathrm{L}$, respectively. From the experimental results it can be concluded that at $\mathrm{pH}$ about 10.5, calcium hydroxide could make the concentrations of heavy metals extremely low. Especially, $\mathrm{Mn}^{2+}$ and $\mathrm{Ni}^{2+}$ concentrations in the treated water appeared to below the detection limit $(<0.001$ $\mathrm{mg} / \mathrm{L}$ ). More than $99 \%$ of $\mathrm{Cu}^{2+}$ and $\mathrm{Zn}^{2+}$ were removed, the residual metal levels, $\mathrm{Cu} 0.12 \mathrm{mg} / \mathrm{L}$ and $\mathrm{Zn} 0.124$ $\mathrm{mg} / \mathrm{L}$, are far below the Chinese discharge limits $(\mathrm{Cu} 0.5-2 \mathrm{mg} / \mathrm{L}, \mathrm{Zn} 2-5 \mathrm{mg} / \mathrm{L})$. Consequently, calcium hydroxide had better effect on the real wastewater than the simulated wastewater.

The $\mathrm{pH}$ working value for each metal is given by the solubility product constant at each $\mathrm{pH}$, which shows an idea of the quantity of the metal dissolved and the quantity in the solid form. Solubility product constants of $\mathrm{Mn}^{2+}$ and $\mathrm{Ni}^{2+}$ hydroxides are known to be $1.9 \times 10^{-13}$ and $2.0 \times 10^{-15}$, respectively (Dean, 2004). It should be very difficult to calculate the solubility of these compounds in the electroplating wastewater exactly. The large amount of impurities, such as organic matter, turbidity, hardness, etc. makes the solubility of the metals become higher, primarily due to the interactions between organic matter and metal (Beltrán \& Sánchez, 2009). Under the premise that the hydroxides are dissolved in the distilled water, the $\mathrm{Mn}^{2+}$ and $\mathrm{Ni}^{2+}$ concentration were 0.1045 $\mathrm{mg} / \mathrm{L}$ and $0.0012 \mathrm{mg} / \mathrm{L}$ when the concentration of these two compounds in the treated water at $\mathrm{pH} 10.5$ were all $<0.001 \mathrm{mg} / \mathrm{L}$. The removal of metal ions under these experimental conditions was dominated by effective co-precipitation.

Nowadays, heavy metals are the environmental priority pollutants, which are faced with more and more stringent regulations. The only way to remove them is to change their chemical and physical states by oxidation/reduction and precipitation. So far, there have been a number of researches that used physical and chemical methods to treat heavy metals-containing wastewater (Table 3-4).

$\mathrm{Cu}^{2+}, \mathrm{Zn}^{2+}, \mathrm{Cr}^{3+}, \mathrm{Pb}^{2+}$ ions were successfully removed by using fly ash as a seed material to enhance precipitation with lime (Chen, Luo, Hills, Xue, \& Tyrer, 2009b). They controlled the pH value to 7-11, the residual concentrations of chromium, copper, lead and zinc in effluents listed in Table 3 showed that the method was successful in reducing the level of soluble heavy metals in solution. In this study, we found the special phenomenon that at $\mathrm{pH} 10.5$ a large amount of calcium carbonates were generated in the solution. By adjusting the $\mathrm{pH}$ to 10.5 with calcium hydroxide, instead of fly ash in the method mentioned above the calcium carbonates generated acted as the seed material, and the $\mathrm{Zn}^{2+}$ and $\mathrm{Pb}^{2+}$ concentrations were decreased to a third. Charerntanyarak (Charerntanyarak, 1999) employed chemical coagulation and precipitation by lime and $\mathrm{Na}_{2} \mathrm{~S}$ to treat synthetic wastewater. He found if coagulant was added, the residual concentration of heavy metal can be decreased further. However, there are potential dangers in applying precipitation with sulfide. Heavy metal ions are often in acid environment while sulfide results in the evolution of toxic $\mathrm{H}_{2} \mathrm{~S}$ fumes easily.

Membrane technology is one option for the separation of heavy metals from wastewater without generating any 
pollution. The membrane process used to remove metals from wastewater includes reverse osmosis (RO), ultrafiltration (UF), nanofiltration (NF) and electrodialysis (ED). Mohsennia et al. (2007) successfully removed $\mathrm{Cu}^{2+}$ and $\mathrm{Ni}^{2+}$ ions by RO process. By using $\mathrm{Na}_{2}$ EDTA, the removal efficiencies of $\mathrm{Cu}^{2+}$ and $\mathrm{Ni}^{2+}$ were more than $99 \%$. The major drawback of RO is the high power consumption due to the pumping pressures, and the restoration of the membranes. As a result, RO has not been widely applied yet. In recent years, Murthy and Chaudhari (Murthy \& Chaudhari, 2008) reported the application of NF-300 membrane for the elimination of $\mathrm{Ni}^{2+}$ from aqueous wastewater. They also investigated the separation capability of NF-300 membrane for binary heavy metals (cadmium \& nickel) from aqueous solutions (Murthy \& Chaudhari, 2009). And these two reports all indicated the removal efficiency of $\mathrm{Ni}^{2+}$ and $\mathrm{Cd}^{2+}$ decreases with concentration increase in influent at constant flow rate. Much smaller than $1.4 \mathrm{mg} / \mathrm{L}$ and $4.02 \mathrm{mg} / \mathrm{L}$ for the treated electroplating wastewater in this study, the final concentration of copper and nickel ions were just $0.12 \mathrm{mg} / \mathrm{L}$ and $0.0003 \mathrm{mg} / \mathrm{L}$ for an initial concentration of $116.54 \mathrm{mg} / \mathrm{L}$ and $198.55 \mathrm{mg} / \mathrm{L}$, the removal rate reached to $99.89 \%$ and $99.99 \%$, respectively. Whatever the initial concentrations were, the final heavy metals concentrations were all extremely low for the method by Murthy and Chaudhari.

Generally, coagulation-flocculation can't remove the heavy metals from wastewater completely (Chang \& Wang, 2007). Coagulation-flocculation must be followed by other treatment techniques. So Beltrán and Sánchez (Beltrán \& Sánchez, 2009) tested a new commercial tannin-based flocculant to remove $\mathrm{Zn}^{2+}, \mathrm{Ni}^{2+}$ and $\mathrm{Cu}^{2+}$ by coagulation-flocculation process. Yuan et al. (2008) investigated the potential of ion flotation for the elimination of $\mathrm{Cd}^{2+}, \mathrm{Pb}^{2+}$ and $\mathrm{Cu}^{2+}$ from dilute aqueous solution with a plant-derived bio-surfactant tea saponin. Its disadvantages involve high initial capital cost, high maintenance and operation costs. The electrochemical (EC) system with aluminium electrodes was used for removing $\mathrm{Mn}^{2+}$ ion and the process which combined the EC system with ectroflotation (EF) / electrocoagulation (EC) cell was investigated on the removal of zinc from synthetic solutions (Casqueira, Torem, \& Kohler, 2006; Shafaei, Rezayee, Arami, \& Nikazar, 2010). The results of their study revealed that $\mathrm{Mn}^{2+}$ removal rate decreased with the initial concentration of the contaminant. Electrochemical treatment techniques, which require fewer chemicals, provide good removal efficiencies and produce less sludge, are regarded rapid and well-controlled. However, the relatively large capital investment and the high electricity supply lead to the limited application of electrochemical wastewater technologies. Due to its selectivity for certain heavy metal ions such as $\mathrm{Pb}^{2+}, \mathrm{Cd}^{2+}, \mathrm{Zn}^{2+}$ and $\mathrm{Cu}^{2+}$, clinoptilolite is one of the most frequently studied natural zeolites (Babel \& Kurniawan, 2003). It can be seen from Table 4 that Doula and Dimirkou (Doula \& Dimirkou, 2008) employed Clin and the Clin-Fe system to simultaneously remove $\mathrm{Cu}^{2+}$, $\mathrm{Mn}^{2+}$ and $\mathrm{Zn}^{2+}$ from drinking water. Compared with the synthetic resin, the use of zeolites as ion-exchange resin is limited at present since ion-exchange resins must be regenerated by chemical reagents when they are exhausted and the regeneration can cause serious secondary pollution. Moreover, the cost is expensive, especially when treating a large amount of wastewater containing heavy metal in low concentration. Consequently, ion-exchange resins cannot be used at large scale.

Although all the above-mentioned treatment techniques can be employed to remove heavy metals from wastewater, each of them has its inherent advantages and limitations. In general, the methods possess high removal efficiency require high capital cost and complex operations. For both the synthetic wastewater and the electroplating wastewater, calcium carbonate generated during the treatment process can serve as a coagulant to greatly remove the heavy metal ions by precipitation, and the ultimate concentrations all could meet the corresponding regulations.

\subsection{Characterization of Sediment}

As is known to all, the crystal particles of $\mathrm{CaCO}_{3}$ are rectangular prisms. Its surface is smooth and the edges and angles are sharp and clear (Figure 4). Many rectangular prisms aggregate and wedge each other together.

In Figure 4 there are some substances with rough surface, attaching on the outside surface of $\mathrm{CaCO}_{3}$. The floccules were also wrapped in various rectangular prisms. Without doubt, the floccules are hydroxides, which have been adsorbed on the outside surface of $\mathrm{CaCO}_{3}$ and wrapped in it. The large amount of $\mathrm{CaCO}_{3}$ generated increased the particle size of the precipitate, improved sedimentation of sludge and the removal efficiency of $\mathrm{Pb}$.

\subsection{Phosphorus and Alga Removal}

\subsubsection{Phosphorus}

Influx of Phosphorus (P) into freshwater ecosystems is the primary cause of eutrophication which has many undesirable effects. Without significant commercial or industrial loads, the influent concentration of total phosphorus in waste water treatment plant (WWTP) effluent may range from $6-8 \mathrm{mg} / \mathrm{L}$ as P (Sengupta \& Pandit, 2011). In this study, the removal efficiency of phosphorus by calcium hydroxide was also investigated in the 
synthetic wastewater. The concentration of P was initially $10.8 \mathrm{mg} / \mathrm{L}$ and finally decreased to $0.379 \mathrm{mg} / \mathrm{L}$, which met the regulatory requirements $(<0.5 \mathrm{mg} / \mathrm{L})$.

Calcium hydroxide was effective to remove the various forms of $P$ in the river water (Figure 5). Experimental results show that most of the phosphorus was removed. The removal rates of TDP and PP were, respectively, $57.05 \%$ and $78.53 \%$, and the final concentration of TP was $0.124 \mathrm{mg} / \mathrm{L}$, for an initial concentration of 0.445 $\mathrm{mg} / \mathrm{L}$. The water quality on TP was improved from worse than class V to class II water.

\subsubsection{Alga}

As a photosynthetic pigment integrating all types of algae, chlorophyll a is a measurable parameter for whole algal production. When the $\mathrm{pH}$ value was decreased to 10.5 , the concentration of chlorophyll a reached 0.009 $\mathrm{mg} / \mathrm{L}$ (Figure 6). According to the fix boundary Chl a criteria system of OECD (1982), after removal, the quality of original water was enhanced from serious eutrophication to mid-eutrophic state.

\subsection{Bio-toxicity Detection}

The purpose of this part was to investigate the effect of exposure to alkalinity on the four organisms which were fancy carp, daphnia, seed, Luminescent bacterium Q67.

There are two key antioxidant defense systems found in many organisms to prevent oxidative stress and maintain health. One consists of antioxidant enzymes including SOD, CAT, et al. SOD plays an important role in the scavenging of superoxide free radicals, which helps to maintain a balance between oxidant and antioxidant. CAT act cooperatively in the liver as scavengers of hydrogen peroxide. MDA is one of the main manifestations of oxidative stress induced by various hepatotoxins (Li, Chung, Kim, \& Lee, 2005).

To investigate the potential impacts of alkaline environment on fancy carp, SOD, CAT and MDA were investigated by two different groups of the fancy carp, one of which was exposed to constant $\mathrm{pH} 10.5$ and the other under natural aeration-scale. MDA, CAT, SOD activities in the liver of the fish after exposure to the natural aerated alkaline environment for 0.5, 1, 2, 5, 8, 12 days are shown in Figure 7. The Figure 7A showed SOD activities in the test group were all lower than the control group. The performance of inhibition on SOD could be seen after 12 hours exposure, which indicated the fancy carp soon produce the stress of oxidation but antioxidant enzymes need a lagging process to react to the stress of oxidation. The activities of antioxidant enzyme (CAT) significantly increased in the livers of the 2th day of alkalinity-exposed fancy carp, as compared to the control fish (Figure 7B). This indicated that toxin-induced oxidative stress activates these antioxidant enzymes to eliminate reactive oxygen species (ROS) and protect cells from lesions. Increased lipid peroxidation was detected from the first day to the fourth day in the present study (Figure 7C). This is probably caused by the environment in which fish lived. But in the eighth day the MDA began to fall, indicating that the damage levels of the body's cells attacked by free radicals were not as serious as the original.

The changes of MDA, CAT, SOD concentration in the experimental fish group exposed at the constant $\mathrm{pH} 10.5$ were shown in Figure 8. The general variation trend of CAT and MDA were similar to the natural aerated group in addition to change very quickly. But there were obvious changes in the absolute concentrations of CAT and MDA. This might be because that the constant $\mathrm{pH}$ value of the water environment made fancy carp greater stress. What's more, Figure $8 \mathrm{~A}$ showed that SOD declined at $12 \mathrm{~h}$ and completely recovered at the 4 th day. The reason was the active oxygen began to inspire, arousing the generation of antioxidant enzymes. With the extension of exposure time, the enzyme activity was down again, since there appears poisoning in the experimental fish owing to the excessive exposure.

What discussed above indicated that the alkalinity had some impact on the fancy carp. Because the aeration made the $\mathrm{pH}$ value fall sharply, the $\mathrm{pH}$ value could decrease to the normal level about 8 in four hours. With the decrease of alkalinity, the damage on the tissue of fish was also weakened.

In the beginning of the daphnia experiment, the test solution with different $\mathrm{pH}$ value was prepared. As shown in Figure 9, the survival rate of daphnia in $24 \mathrm{~h}$ was $100 \%$ when $\mathrm{pH}$ value was not more than 10.5 . Decreased survival rate ( $75 \%$ and $37.5 \%$, respectively) was observed at the $\mathrm{pH}$ value of 10.8 and 11.0 after $24 \mathrm{~h}$. These phenomena indicated that the solution with $\mathrm{pH}$ less than 10.5 had a little adverse effect on the daphnia. When the $\mathrm{pH}$ of the solution was adjusted to 11.3 with calcium hydroxide, daphnia was all dead. This may be caused by the joint toxicity of calcium ion and alkalinity. Along, the concentration of calcium ions increased rapidly after $\mathrm{pH}$ 10.6 with the continuous addition of calcium hydroxide.

It was suggested from Figure 9 that the relationship between inhibition rate of seed germination and the $\mathrm{pH}$ value appeared to be positively correlated. The $\mathrm{GC}_{50}$ of the cabbage seeds was found at $\mathrm{pH} 12.05$. 
The $\mathrm{pH}$ value at which the relative luminance was $50 \%$, also regarded as the $\mathrm{pH}$ value of half luminescence inhibition against $Q 67\left(\mathrm{EC}_{50}\right)$, was obtained with linear interpolation method. The standard errors of three parallel experiments for each $\mathrm{pH}$ value were less than $10 \%$. The $\mathrm{EC}_{50}$ value for $Q 67$ was 11.13 , respectively.

In summary, alkalinity had a poisonous effect on the four tested organisms and the different effect among $\mathrm{pH}$ values was significant. It can be thought that the toxicity of the alkaline solution at the adjusted $\mathrm{pH}$ value of 10.5 , as well as the smaller $\mathrm{pH}$ under natural aeration, on the living beings was slight. $100 \%$ seed germination was observed at the $\mathrm{pH}$ value 10.5. Both Daphnia and Q67 did not show the poisoning symptoms. Consequently, $\mathrm{pH}$ 10.5 adjusted by calcium hydroxide had little influence to the organisms under natural aeration.

\section{Conclusions}

In this study, we found a phenomenon that the concentration of calcium ion was minimal when $\mathrm{pH}$ was adjusted to the golden point of 10.5 with calcium hydroxide. The precipitation of heavy metals with calcium hydroxide which adjusted the $\mathrm{pH}$ value of wastewater to 10.5 was shown to be successful in reducing the concentration of soluble heavy metals. The generated calcium carbonate improved the removal efficiency of heavy metals from the synthetic wastewater and electroplating wastewater, making the residual concentration meet regulatory requirements. Compared with the conventional methods, the precipitation with calcium hydroxide adjusting the $\mathrm{pH}$ to 10.5 has several advantages: high removal efficiency, low operating cost, production of more concentrated sludge and little influence to the aquatic organisms. What's more, the method also has very good effect on the removal of algae and P. Precipitation, coagulation, flocculation with calcium hydroxide for the adjustment of the $\mathrm{pH}$ value to 10.5 can also be used to remove algae from eutrophication water. It was, therefore, apparent that the method would be robust for application in treating the problem water, for example, micro-polluted water, heavy metal-containing industrial wastewater and eutrophication water.

\section{References}

Argun, M. E. (2008). Use of clinoptilolite for the removal of nickel ions from water: Kinetics and thermodynamics. Journal of Hazardous Materials, $150(3), \quad$ 587-59. http://dx.doi.org/10.1016/j.jhazmat.2007.05.008

Babel, S., \& Kurniawan, T. A. (2003). Low cost adsorbents for heavy metals uptake from contaminated water: a review. Journal of Hazardous Materials, B97, 219-243. http://dx.doi.org/10.1016/S0304-3894(02)00263-7

Baek, K., \& Yang, J. W. (2004). Cross-flow micellar-enhanced ultrafiltration for removal of nitrate and chromate: competitive binding. Journal of Hazardous Materials, 108(1-2), 184-191. http://dx.doi.org/10.1016/j.jhazmat.2004.02.001

Beltrán, H. J., \& Sánchez, M. J. (2009). Removing heavy metals from polluted surface water with a tannin-based flocculant agent. Journal of Hazardous Materials, 165(1-3), 1215-1218. http://dx.doi.org/10.1016/j.jhazmat.2008.09.104

Bhattacharjee, S., Chakrabarty, S., Maity, S., Kar, S., Thakur, P., \& Bhattacharyya, G. (2003). Removal of lead from contaminated water bodies using sea nodule as an adsorbent. Water Research, 37(16), 3954-3966. http://dx.doi.org/10.1016/S0043-1354(03)00315-4

Borba, C., Guirardello, R., Silva, E., Veit, M., \& Tavares, C. (2006). Removal of nickel (II) ions from aqueous solution by biosorption in a fixed bed column: Experimental and theoretical breakthrough curves. Biochemical Engineering Journa, 30(2), 184-191. http://dx.doi.org/10.1016/j.bej.2006.04.001

Capponi, F., Sartori, M., Souza, M., \& Rubio, J. (2006). Modified column flotation of adsorbing iron hydroxide colloidal precipitates. International Journal of Mineral Processing, 79(3), 167-173. http://dx.doi.org/10.1016/j.minpro.2006.02.002

Casqueira, R., Torem, M., \& Kohler, H. (2006). The removal of zinc from liquid streams by electroflotation. Minerals Engineering, 19(13), 1388-1392. http://dx.doi.org/10.1016/j.mineng.2006.02.001

Chaabane, T., Taha, S., Talebahmed, M., Maachi, R., \& Dorange, G. (2006). Removal of copper from industrial effluent using a spiral wound module - film theory and hydrodynamic approach. Desalination, 200(1-3), 403-405. http://dx.doi.org/10.1016/j.desal.2006.03.348

Chang, Q., \& Wang, G. (2007). Study on the macromolecular coagulant PEX which traps heavy metals. Chemical Engineering Science, 62(17), 4636-4643. http://dx.doi.org/10.1016/j.ces.2007.05.002

Charerntanyarak, L. (1999). Heavy metals removal by chemical coagulation and precipitation. Water Science and Technology, 39, 135-138. http://dx.doi.org/10.1016/S0273-1223(99)00304-2 
Chen, X., He, S., Huang, Y., Kong, H., Lin, Y., Li, C., \& Zeng, G. (2009a). Laboratory investigation of reducing two algae from eutrophic water treated with light-shading plus aeration. Chemosphere, 76(9), 1303-1307. http://dx.doi.org/10.1016/j.chemosphere.2009.05.027

Chen, Q., Luo, Z., Hills, C., Xue, G., \& Tyrer, M. (2009b). Precipitation of heavy metals from wastewater using simulated flue gas: Sequent additions of fly ash, lime and carbon dioxide. Water Research, 43(10), 2605-2614. http://dx.doi.org/10.1016/j.watres.2009.03.007

Dean, J. A. (2004). Dean's Analytical Chemistry Handbook. (New York: McGraw-Hill).

Doula, M. K., \& Dimirkou, A. (2008). Use of an iron-overexchanged clinoptilolite for the removal of $\mathrm{Cu}^{2+}$ ions from heavily contaminated drinking water samples. Journal of Hazardous Materials, 151(2-3), 738-745. http://dx.doi.org/10.1016/j.jhazmat.2007.06.047

$\mathrm{Fu}, \mathrm{F} .$, \& Wang, Q. (2011). Removal of heavy metal ions from wastewaters: A review. Journal of Environmental Management, 92(3), 407-418. http://dx.doi.org/10.1016/j.jenvman.2010.11.011

Garland, J. L., Levine, L. H., Yorio, N. C., \& Hummerick, M. E. (2004). Response of graywater recycling systems based on hydroponic plant growth to three classes of surfactants. Water Research, 38(8), 1952-1962. http://dx.doi.org/10.1016/j.watres.2004.01.005

Huisman, J., Schouten, G., \& Schultz, C. (2006). Biologically produced sulphide for purification of process streams, effluent treatment and recovery of metals in the metal and mining industry. Hydrometallurgy, 83(1-4), 106-113. http://dx.doi.org/10.1016/j.hydromet.2006.03.017

Inglezakis, V. (2003). Modeling of ion exchange of $\mathrm{Pb}^{2+}$ in fixed beds of clinoptilolite. Microporous and Mesoporous Materials, 61(1-3), 273-282. http://dx.doi.org/10.1016/S1387-1811(03)00374-3

ISO 10260. (1992). Water quality-measurement of biochemical parameters-spectrometric determination of the chlorophyll-a concentration. International Organization for Standardization, Geneva, Switzerland, 1-6.

ISO 6341. (1996). Water quality-determination of the inhibition of the mobility of Daphnia magna Straus (Cladocera, Crustacea). Acute toxicity test. International Organization for Standardization, Geneva, Switzerland. $1-9$.

Khelifa, A., Moulay, S., \& Naceur, A. (2005). Treatment of metal finishing effluents by the electroflotation technique. Desalination, 181(1-3), 27-33. http://dx.doi.org/10.1016/j.desal.2005.01.011

$\mathrm{Ku}, \mathrm{Y}$., \& Jung, I. L. (2001). Photocatalytic reduction of $\mathrm{Cr}(\mathrm{VI})$ in aqueous solutions by UV irradiation with the presence of titanium dioxide. Water Research, 35, 135-142. http://dx.doi.org/10.1016/S0043-1354(00)00098-1

Li, X., Chung, I., Kim, J., \& Lee, J. (2005). Oral exposure to increases activity-augmented antioxidant enzymes in the liver of loach (Misgurnus mizolepis) and has no effect on lipid peroxidation. Comparative Biochemistry and Physiology Part C: Toxicology \& Pharmacology, 141(3), 292-296. http://dx.doi.org/10.1016/j.cca.2005.07.004

Martin, T. D., \& Katrin, T. (2000). Cyanobacterial dominance in lakes. Hydrobiologia, 438, 1-12. http://dx.doi.org/10.1023/A:1004155810302

Mohsennia, M., Montazeri, P., \& Modarress, H. (2007). Removal of $\mathrm{Cu}^{2+}$ and $\mathrm{Ni}^{2+}$ from wastewater with a chelating agent and reverse osmosis processes. Desalination, 217(1-3), 276-281. http://dx.doi.org/10.1016/j.desal.2006.01.043

Murphy, J., \& Riley, J. P. (1962). A modified single solution method for the determination of phosphate in natural waters. Analytica Chimica Acta, 27, 31-36. http://dx.doi.org/10.1016/S0003-2670(00)88444-5

Murthy, Z. V. P., \& Chaudhari, L. B. (2008). Application of nanofiltration for the rejection of nickel ions from aqueous solutions and estimation of membrane transport parameters. Journal of Hazardous Materials, 160(1), 70-77. http://dx.doi.org/10.1016/j.jhazmat.2008.02.085

Murthy, Z. V. P., \& Chaudhari, L. B. (2009). Separation of binary heavy metals from aqueous solutions by nanofiltration and characterization of the membrane using Spiegler-Kedem model. Chemical Engineering Journal, 150(1), 181-187. http://dx.doi.org/10.1016/j.cej.2008.12.023

Oyaro, N., Juddy, O., Murago, E. N. M., \& Gitonga, E. (2007). The contents of $\mathrm{Pb}, \mathrm{Cu}, \mathrm{Zn}$ and $\mathrm{Cd}$ in meat in nairobi, Kenya. Journal of Food Agriculture \& Environment, 5(3-4), 119-121.

Paerl, H. W., Xu, H., McCarthy, M. J., Zhu, G., Qin, B., Li, Y., \& Gardner, W. S. (2011). Controlling harmful cyanobacterial blooms in a hyper-eutrophic lake (Lake Taihu, China): The need for a dual nutrient (N \& P) 
management strategy. Water Research, 45(5), 1973-1983. http://dx.doi.org/10.1016/j.watres.2010.09.018

Paulino, A., Minasse, F., Guilherme, M., Reis, A., Muniz, E., \& Nozaki, J. (2006). Novel adsorbent based on silkworm chrysalides for removal of heavy metals from wastewaters. Journal of Colloid and Interface Science, 301(2), 479-487. http://dx.doi.org/10.1016/j.jcis.2006.05.032

Sengupta, S., \& Pandit, A. (2011). Selective removal of phosphorus from wastewater combined with its recovery as a solid-phase fertilizer. Water Research, 45(11), 3318-3330. http://dx.doi.org/10.1016/j.watres.2011.03.044

Shafaei, A., Rezayee, M., Arami, M., \& Nikazar, M. (2010). Removal of $\mathrm{Mn}^{2+}$ ions from synthetic wastewater by electrocoagulation process. Desalination, 260(1-3), 23-28. http://dx.doi.org/10.1016/j.desal.2010.05.006

Smith, V. H., Tilman, G. D., \& Nekola, J. C. (1999). Eutrophication impacts of excess nutrient inputs on freshwater, marine, and terrestrial ecosystems. Environmental pollution, 100, 179-196. http://dx.doi.org/10.1016/S0269-7491(99)00091-3

Stéphanie, L. L., Lecomte, P., \& Ehrhardt, J. J. (2001). Behavior of hexavalent chromium in a polluted groundwater: Redox processes and immobilization in soils. Environmental Science \& Technology, 35(7), 1350-1357. http://dx.doi.org/10.1021/es0010731

Sudilovskiy, P., Kagramanov, G., \& Kolesnikov, V. (2008). Use of RO and NF for treatment of copper containing wastewaters in combination with flotation. Desalination, 221(1-3), 192-201. http://dx.doi.org/10.1016/j.desal.2007.01.076

Tsai, L. J., Yu, K. C., Chen, S. F., \& Kung, P. Y. (2003). Effect of temperature on removal of heavy metals from contaminated river sediments via bioleaching. Water Research, 37(10), 2449-2457. http://dx.doi.org/10.1016/S0043-1354(02)00634-6

Wang, L. K., Vaccari, D. A., Li, Y., \& Shammas, N. K. (2005). Chemical precipitation, in: L.K. Wang, Y.T. Hung, N.K. Shammas, N.K., Physicochemical Treatment Processes, vol. 3, Humana Press, New Jersey, 141-197. http://dx.doi.org/10.1385/1-59259-820-x:141

Yuan, X. Z., Meng, Y. T., Zeng, G. M., Fang, Y. Y., \& Shi, J. G. (2008). Evaluation of tea-derived biosurfactant on removing heavy metal ions from dilute wastewater by ion flotation. Colloids and Surfaces A: Physicochemical and Engineering Aspects, 317(1-3), 256-261. http://dx.doi.org/10.1016/j.colsurfa.2007.10.024

Table 1. Jar tests with simulation wastewater by calcium hydroxide and sodium hydroxide

\begin{tabular}{cccccccccccccc}
\hline & \multicolumn{1}{c}{ Heavy metal concentration $(\mathrm{mg} / \mathrm{L})$} \\
\cline { 2 - 13 } $\mathrm{pH}$ & \multicolumn{1}{c}{ Sodium hydroxide } \\
\cline { 2 - 13 } & $\mathrm{Cd}$ & $\mathrm{Mn}$ & $\mathrm{Zn}$ & $\mathrm{Ni}$ & $\mathrm{Cu}$ & $\mathrm{Pb}$ & $\mathrm{Cd}$ & $\mathrm{Mn}$ & $\mathrm{Zn}$ & $\mathrm{Ni}$ & $\mathrm{Cu}$ & $\mathrm{Pb}$ \\
\hline 7 & $\mathrm{NA}$ & 4.664 & 4.589 & $\mathrm{NA}$ & 2.059 & $\mathrm{NA}$ & $\mathrm{NA}$ & 4.653 & 5.012 & $\mathrm{NA}$ & 2.037 & $\mathrm{NA}$ \\
\hline 8 & $\mathrm{NA}$ & 3.748 & 0.664 & 1.910 & 1.482 & 0.147 & $\mathrm{NA}$ & 3.964 & 0.945 & 1.954 & 1.303 & 0.155 \\
\hline 9 & 0.031 & 2.974 & 0.092 & 1.740 & 1.349 & 0.114 & 0.034 & 1.732 & 0.040 & 1.454 & 0.941 & 0.135 \\
\hline 10 & 0.006 & 0.615 & 0.0008 & 0.648 & 1.107 & 0.043 & 0.002 & 0.422 & 0.021 & 0.700 & 0.566 & 0.028 \\
\hline 10.5 & 0.002 & 0.204 & 0.011 & 0.453 & 0.815 & 0.023 & 0.001 & 0.082 & 0.012 & 0.259 & 0.066 & 0.016 \\
\hline 11 & 0.003 & 0.005 & 0.013 & 0.428 & 0.854 & 0.041 & 0.0008 & $\mathrm{ND}$ & 0.027 & 0.091 & 0.033 & 0.017 \\
\hline
\end{tabular}

NA: not available; ND: not detect. 
Table 2. Jar tests with simulation wastewater by calcium hydroxide

\begin{tabular}{ccccccc}
\hline \multirow{2}{*}{$\mathrm{pH}$} & \multicolumn{7}{c}{ Heavy metal concentration $(\mathrm{mg} / \mathrm{L})$} \\
\cline { 2 - 7 } & $\mathrm{Cd}$ & $\mathrm{Mn}$ & $\mathrm{Zn}$ & $\mathrm{Ni}$ & $\mathrm{Cu}$ & $\mathrm{Pb}$ \\
\hline 6 & $\mathrm{NA}$ & $\mathrm{NA}$ & $\mathrm{NA}$ & $\mathrm{NA}$ & 150 & $\mathrm{NA}$ \\
\hline 7 & $\mathrm{NA}$ & $\mathrm{NA}$ & $\mathrm{NA}$ & $\mathrm{NA}$ & 2.723 & $\mathrm{NA}$ \\
\hline 8 & $\mathrm{NA}$ & 65.040 & 14.020 & 10.210 & 1.258 & $\mathrm{NA}$ \\
\hline 9 & 0.079 & 48.680 & 0.874 & 6.160 & 1.170 & 0.688 \\
\hline 10 & 0.012 & 2.192 & 0.267 & 1.220 & 0.917 & 0.388 \\
\hline 10.5 & 0.002 & 0.416 & 0.093 & 0.451 & 0.948 & 0.020 \\
\hline 11 & 0.003 & 0.071 & 0.185 & 0.200 & 1.128 & 0.014 \\
\hline
\end{tabular}

NA: not available.

Table 3. A list of some selected examples of heavy metal removal by chemical precipitation, membrane filtration, coagulation and flocculation, flotation, electrochemical treatment

\begin{tabular}{|c|c|c|c|c|c|}
\hline Methods & Species & Conditions & $\begin{array}{l}\text { Ultimate metal } \\
\text { conc. }\end{array}$ & $\begin{array}{l}\text { Removal } \\
\text { efficiency }\end{array}$ & Ref. \\
\hline \multirow{2}{*}{$\begin{array}{l}\text { chemical } \\
\text { precipitation }\end{array}$} & $\begin{array}{l}\mathrm{Cu}^{2+}, \mathrm{Zn}^{2+} \\
\mathrm{Cr}^{3+}, \mathrm{Pb}^{2+}\end{array}$ & $\begin{array}{c}\text { fly ash-lime-carbonation } \\
\text { treatment }\end{array}$ & $\begin{array}{c}0.14,0.45 \\
0.08,0.03 \mathrm{mg} / \mathrm{L}\end{array}$ & $99.37-99.6$ & $\begin{array}{l}\text { (Chen et al., } \\
\text { 2009b) }\end{array}$ \\
\hline & $\begin{array}{l}\mathrm{Zn}^{2+}, \mathrm{Cd}^{2+}, \\
\mathrm{Mn}^{2+}, \mathrm{Mg}^{2+}\end{array}$ & $\mathrm{Na}_{2} \mathrm{~S}$-lime & $\begin{array}{c}0.4,<0.1,0.7 \\
5 \mathrm{mg} / \mathrm{L}\end{array}$ & $50-99.59$ & $\begin{array}{l}\text { (Charerntanyarak, } \\
\text { 1999) }\end{array}$ \\
\hline \multirow{3}{*}{$\begin{array}{l}\text { membrane } \\
\text { filtration }\end{array}$} & $\mathrm{Cu}^{2+}, \mathrm{N}^{\mathrm{i} 2+}$ & $\begin{array}{l}\text { RO- EDTA -operation } \\
\text { pressure } \\
5 \mathrm{~atm}\end{array}$ & $1.4,4.02 \mathrm{mg} / \mathrm{L}$ & $99.14-99.72$ & $\begin{array}{l}\text { (Mohsennia et al., } \\
\text { 2007) }\end{array}$ \\
\hline & $\mathrm{Cu}^{2+}$ & $\begin{array}{l}\text { NF-transmembrane } \\
\text { pressure(1-3bar) }\end{array}$ & $\begin{array}{c}236.8-339.2 \\
\mathrm{mg} / \mathrm{L}\end{array}$ & $47-66$ & $\begin{array}{l}\text { (Chaabane et al., } \\
\text { 2006) }\end{array}$ \\
\hline & $\mathrm{Cu}^{2+}$ & $\begin{array}{l}\mathrm{RO}+\mathrm{NF}-\text { combination of } \\
\text { flotation and membrane } \\
\quad \text { filtration, } 3.8 \mathrm{bar}\end{array}$ & $0.15-0.75 \mathrm{mg} / \mathrm{L}$ & $95-99$ & $\begin{array}{l}\text { (Sudilovskiy et } \\
\text { al., 2008) }\end{array}$ \\
\hline $\begin{array}{l}\text { coagulation } \\
\text { and } \\
\text { flocculation }\end{array}$ & $\begin{array}{l}\mathrm{Zn}^{2+}, \mathrm{Cu}^{2+} \\
\mathrm{N}^{\mathrm{i} 2+}\end{array}$ & $\begin{array}{c}\text { Tanfloc with an } \\
\text { optimum value in } 7,6 \text { and } 8\end{array}$ & $5,2,6 \mathrm{mg} / \mathrm{L}$ & $75,90,70$ & $\begin{array}{l}\text { (Beltrán \& } \\
\text { Sánchez, 2009) }\end{array}$ \\
\hline \multirow{2}{*}{ flotation } & $\begin{array}{c}\mathrm{Cu}^{2+} \\
\mathrm{Cd}^{2+}, \mathrm{Pb}^{2+}\end{array}$ & $\begin{array}{l}\text { ion flotation when the ratio } \\
\text { of collector to metal was } 3: 1\end{array}$ & $\begin{array}{l}0.121 \mathrm{mg} / \mathrm{L} \\
0.323 \mathrm{mg} / \mathrm{L} \\
0.208 \mathrm{mg} / \mathrm{L}\end{array}$ & $\begin{array}{c}81.13 \\
71.17,89.95\end{array}$ & (Yuan et al., 2008) \\
\hline & $\begin{array}{l}\mathrm{Cu}^{2+}, \mathrm{N}^{\mathrm{i} 2+} \\
\mathrm{Zn}^{2+}, \mathrm{Cd}^{2+}\end{array}$ & $\begin{array}{l}\text { colloidal ferric hydroxide } \\
\text { precipitate- a modified } \\
\text { column flotation }\end{array}$ & $\begin{array}{l}0.4,0.8,0.9 \\
0.2 \mathrm{mg} / \mathrm{L}\end{array}$ & $90-99$ & $\begin{array}{l}\text { (Capponi et al., } \\
\text { 2006) }\end{array}$ \\
\hline \multirow{3}{*}{$\begin{array}{l}\text { electrochemical } \\
\text { treatment }\end{array}$} & $\mathrm{Mn}^{2+}$ & $\begin{array}{l}\text { EC process with aluminium } \\
\text { electrodes, current density } \\
\text { of } 6.25 \mathrm{~mA} / \mathrm{cm}^{2}\end{array}$ & $21.7 \mathrm{mg} / \mathrm{L}$ & 78.2 & $\begin{array}{l}\text { (Shafaei et al., } \\
\text { 2010) }\end{array}$ \\
\hline & $\mathrm{Zn}^{2+}$ & $\begin{array}{c}\text { electroflotation - sodium } \\
\text { dodecyl sulfate (SDS) as } \\
\text { collector in the } \\
\text { stoichiometric ratio } 1: 3, \\
\text { current density of around } 8 \\
\mathrm{~mA} / \mathrm{cm}^{2}\end{array}$ & $0.8 \mathrm{mg} / \mathrm{L}$ & 96 & $\begin{array}{l}\text { Casqueira et al., } \\
2006\end{array}$ \\
\hline & $\mathrm{Ni}^{2+}, \mathrm{Cu}^{2+}$ & $\begin{array}{c}\text { Electroflotation: Current } 0.3 \\
\mathrm{~mA}\end{array}$ & $1 \mathrm{mg} / \mathrm{L}$ & $98-99$ & $\begin{array}{l}\text { (Khelifa et al., } \\
\text { 2005) }\end{array}$ \\
\hline
\end{tabular}


Table 4. Heavy metal removal using chemical ion-exchange

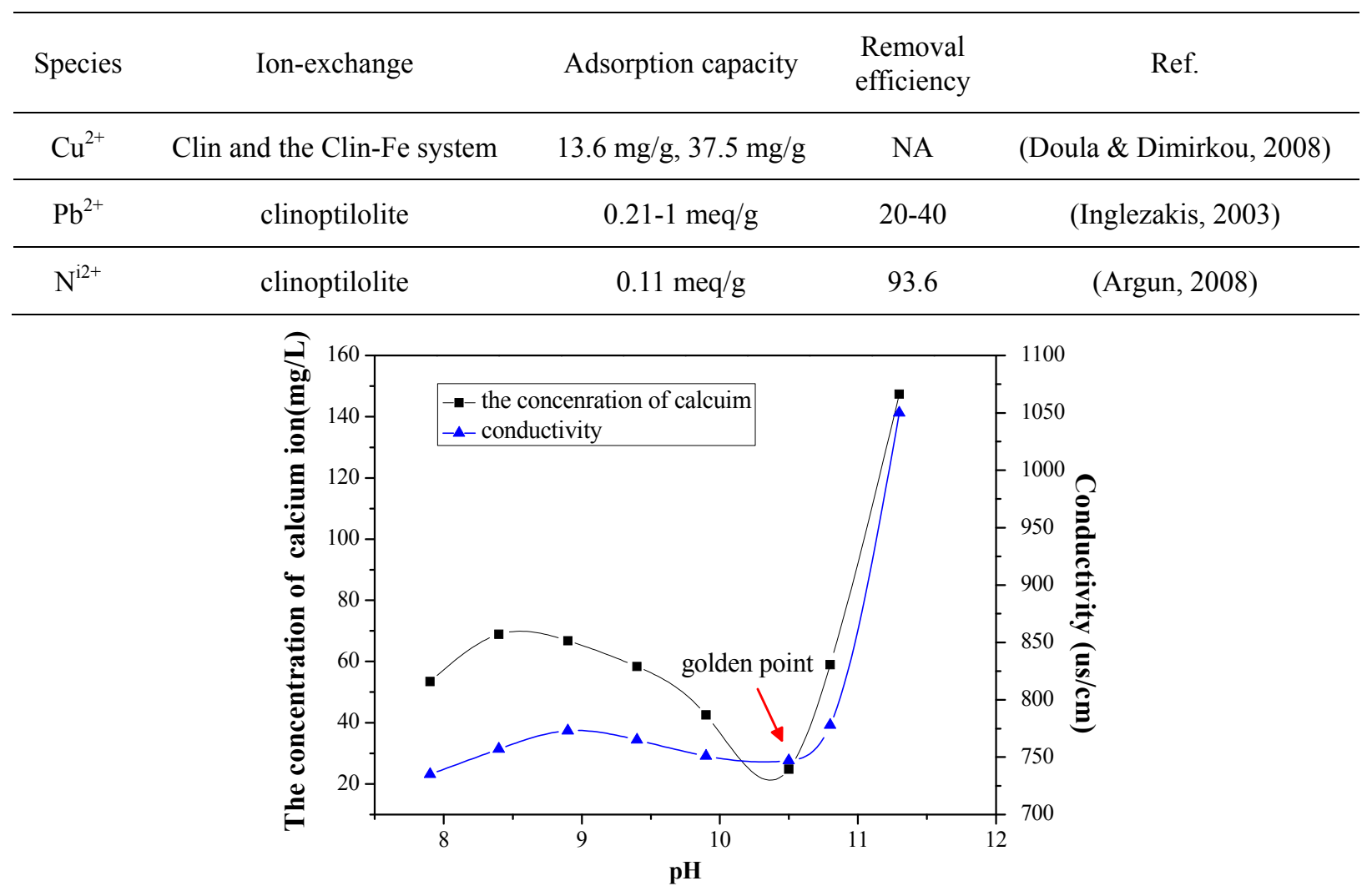

Figure 1 . The effect of $\mathrm{pH}$ on the concentration of calcium ion and the conductivity

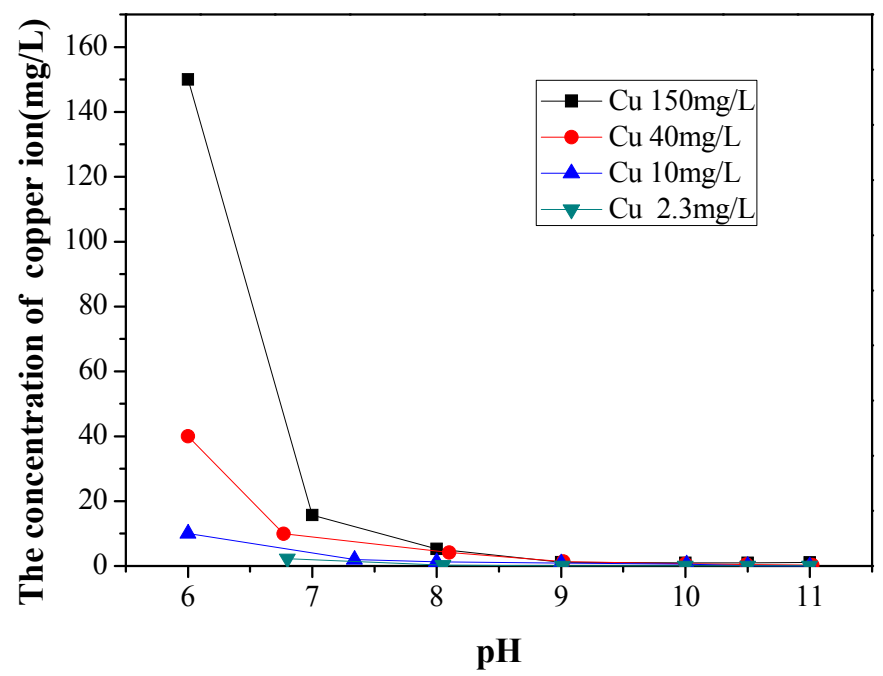

Figure 2. The effect of $\mathrm{pH}$ on the concentration of copper ion with different initial concentration 

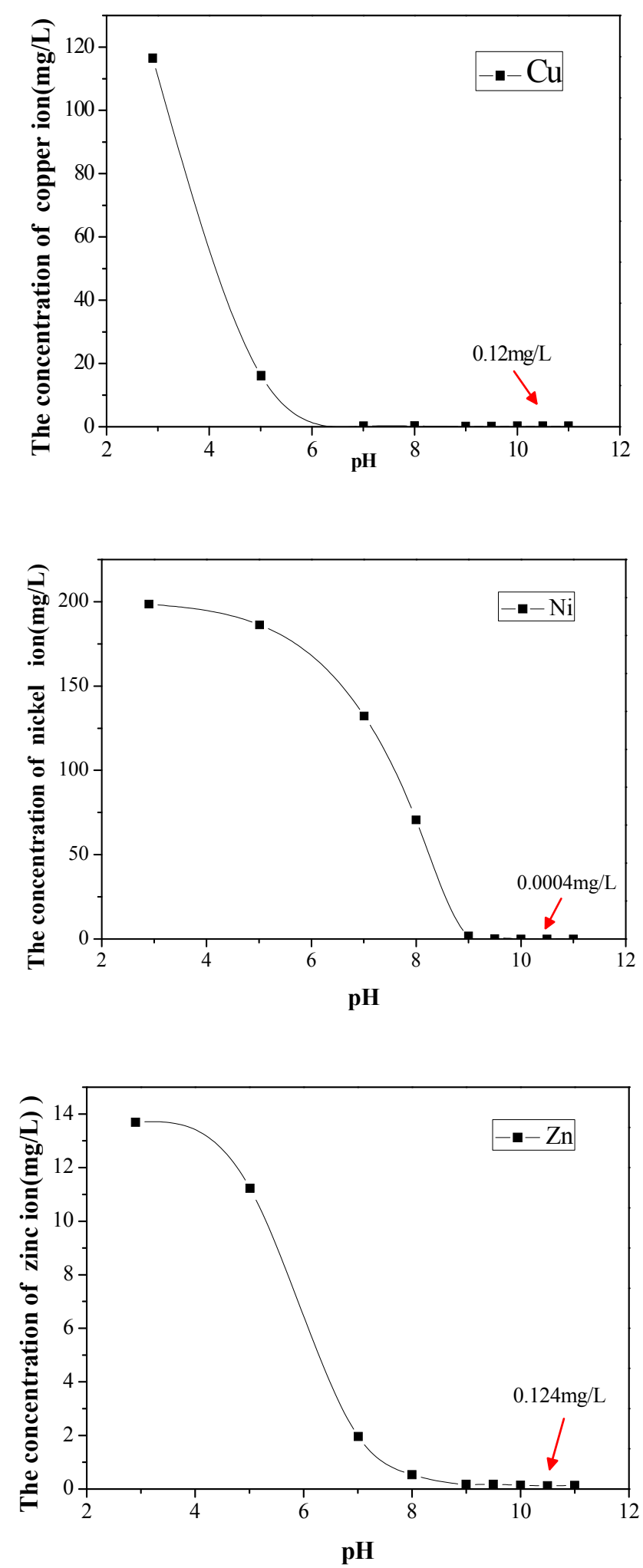


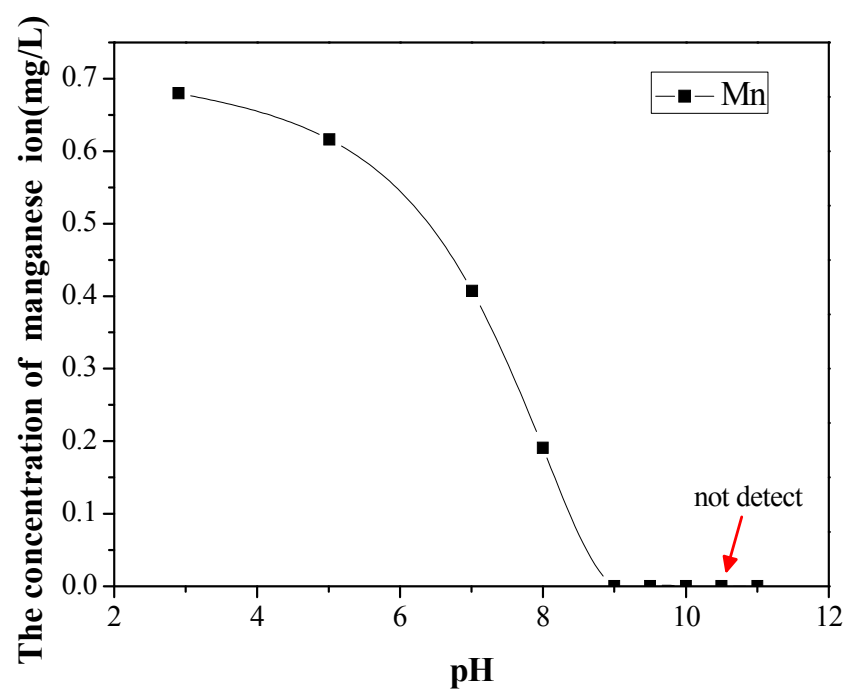

Figure 3. The relationship between $\mathrm{pH}$ and the concentration of $\mathrm{Cu}, \mathrm{Ni}, \mathrm{Zn}$ and $\mathrm{Mn}$ ion

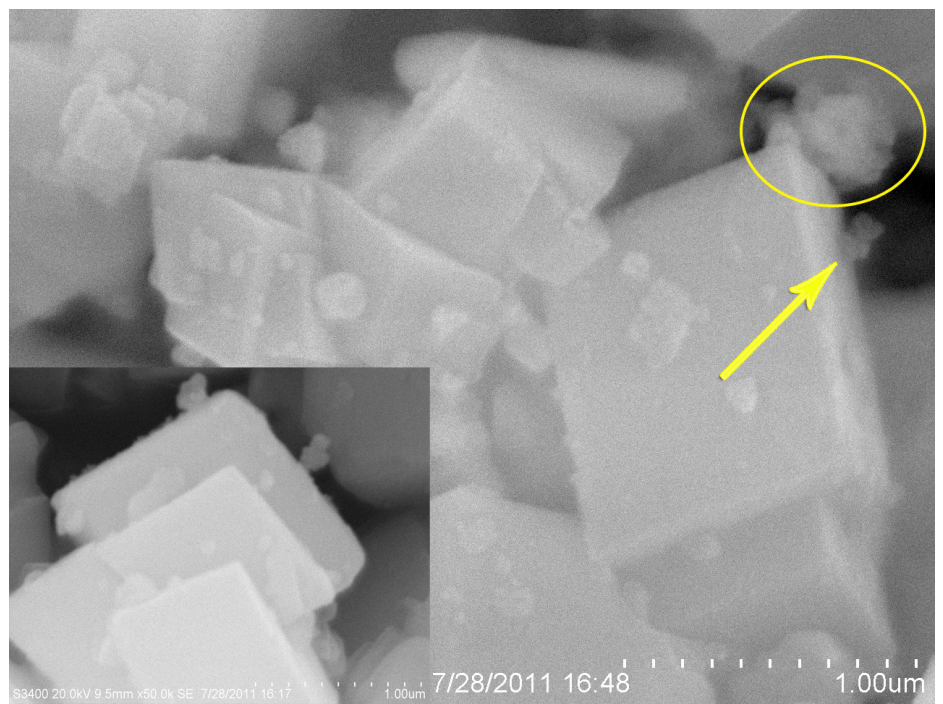

Figure 4. SEM images of $\mathrm{Pb}$ as hydroxide attached on $\mathrm{CaCO}_{3}$

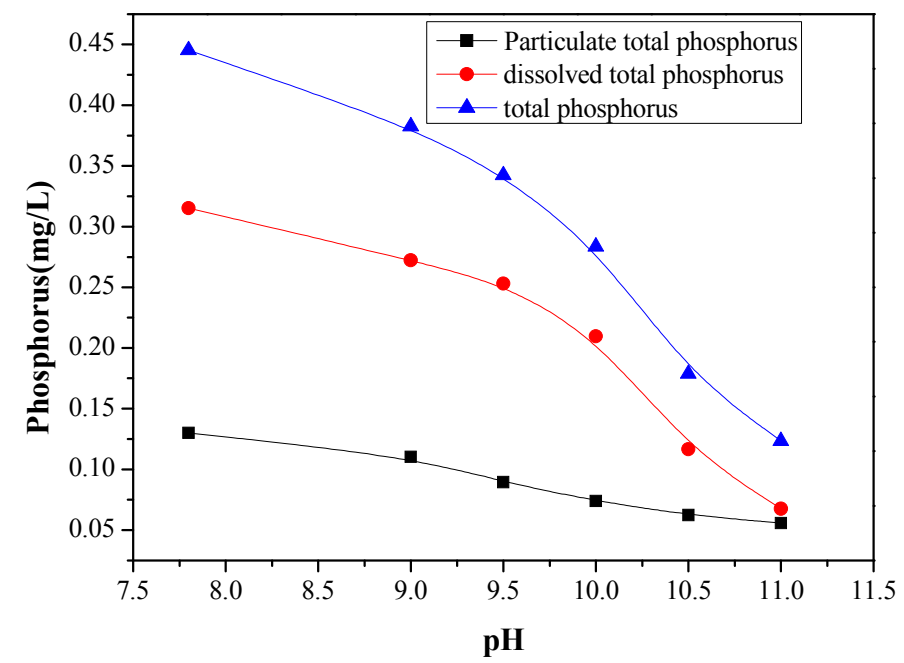

Figure 5. The concentration varying trends of TP, TDP and PP at different PH value 


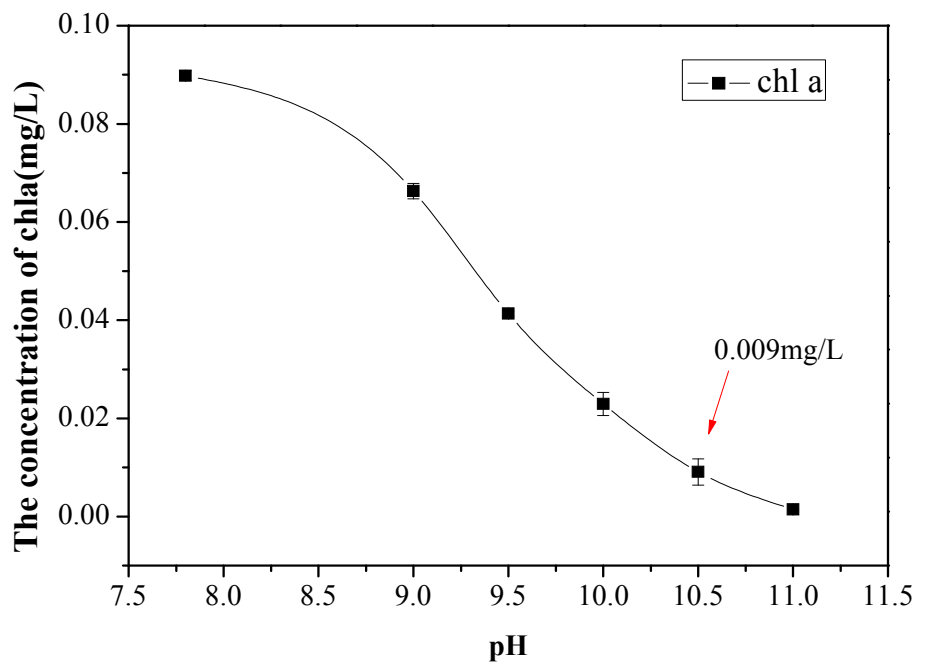

Figure 6. The relationship between $\mathrm{pH}$ and the concentration of chl a
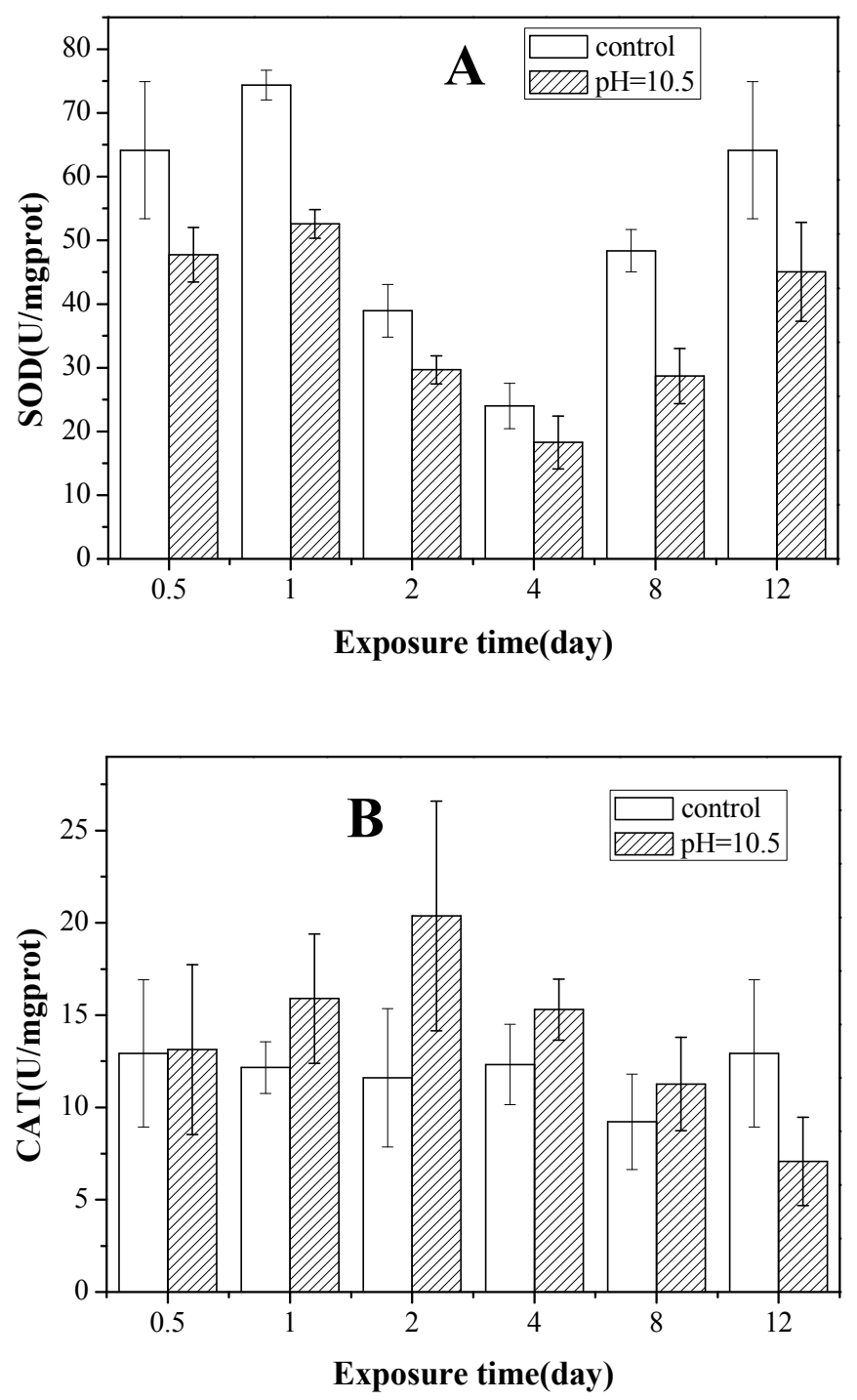


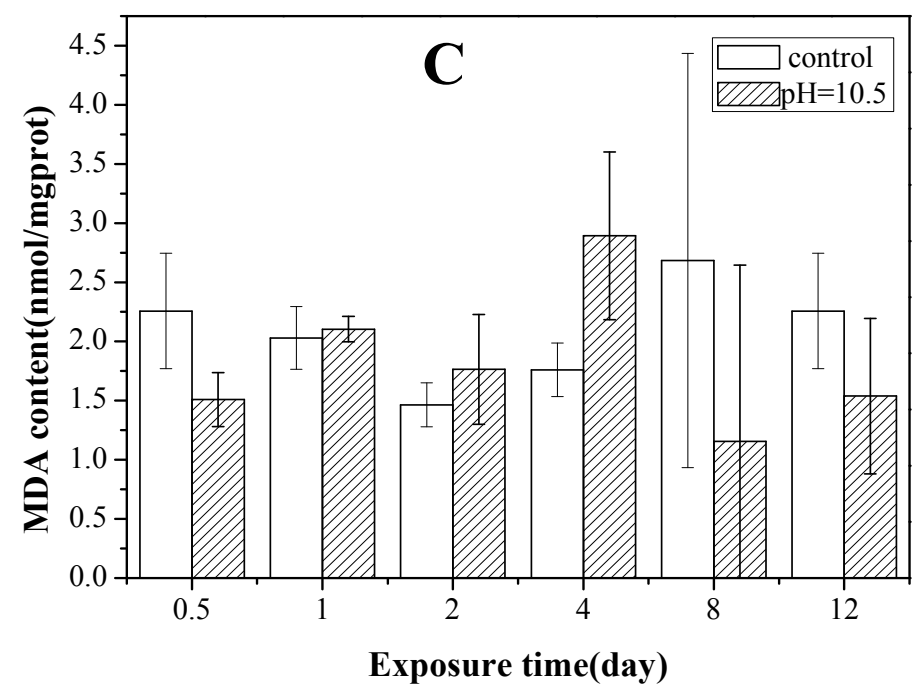

Figure 7. The level of SOD, CAT and MDA in the liver of fish which were exposed to alkalinity under natural aeration-scale in different time. Values were presented as the mean of three individual fish
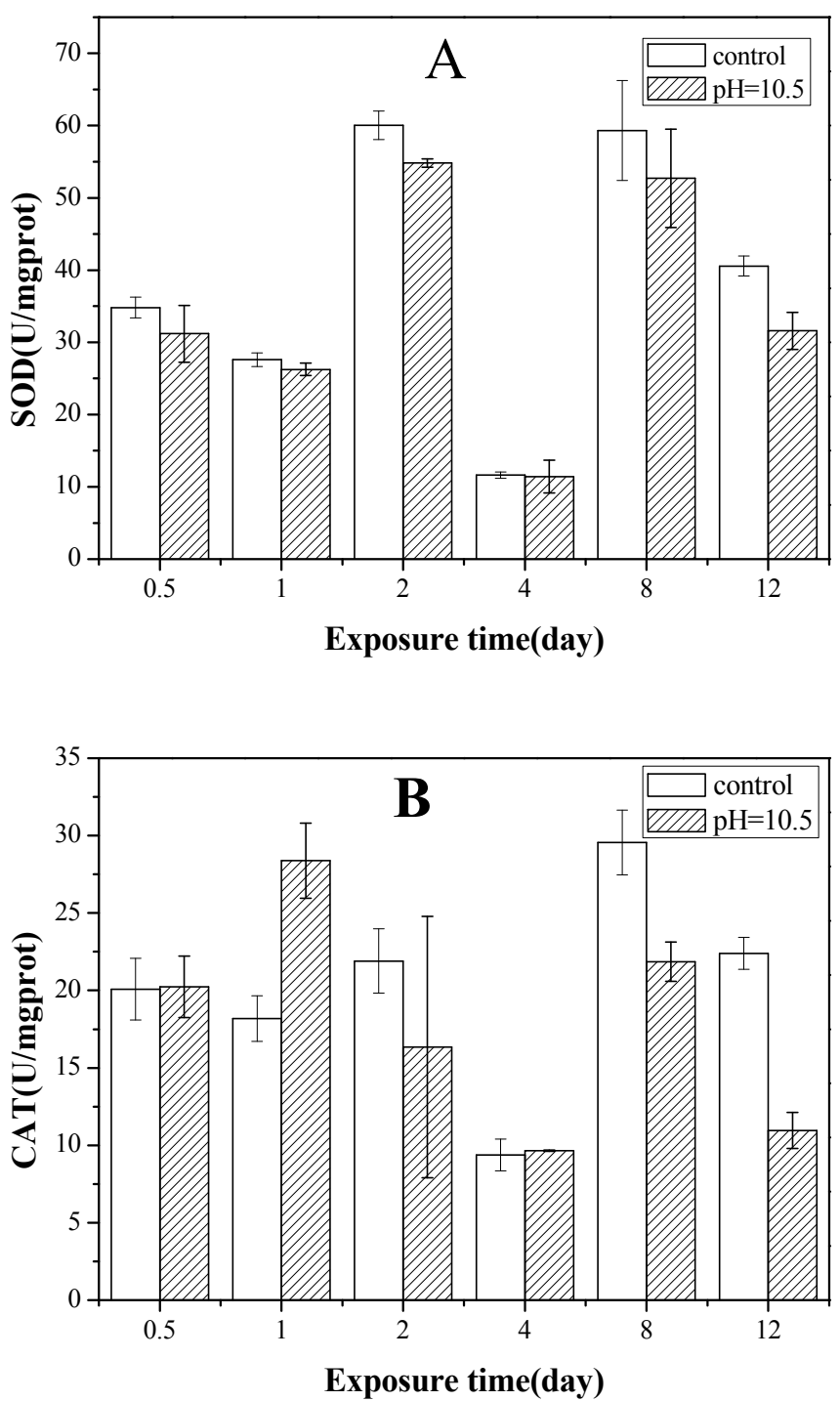


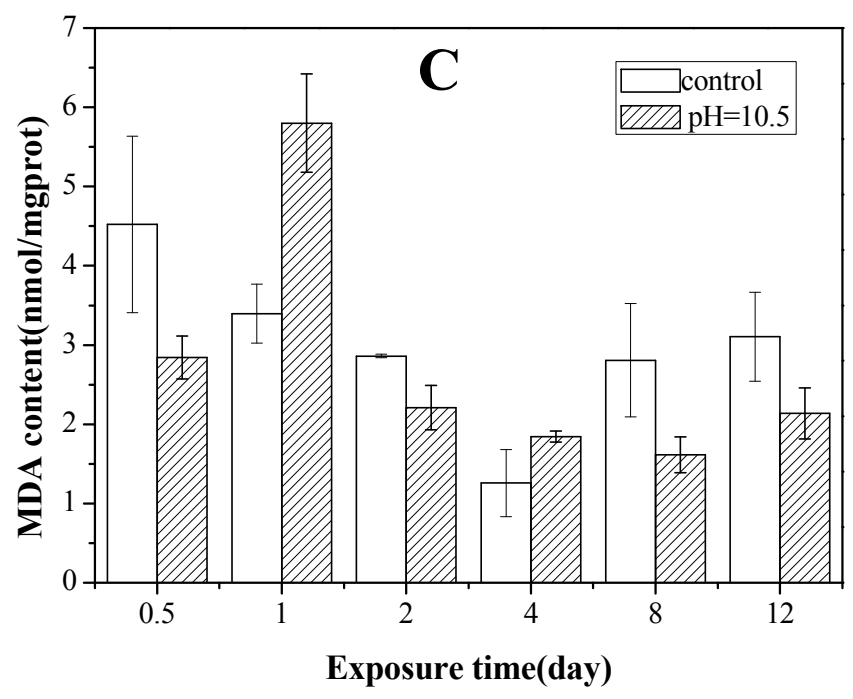

Figure 8. The SOD, CAT and MDA level in the liver of fish after different exposure time to alkalinity at the constant $\mathrm{pH} 10.5$. Values were presented as the mean of three individual fish

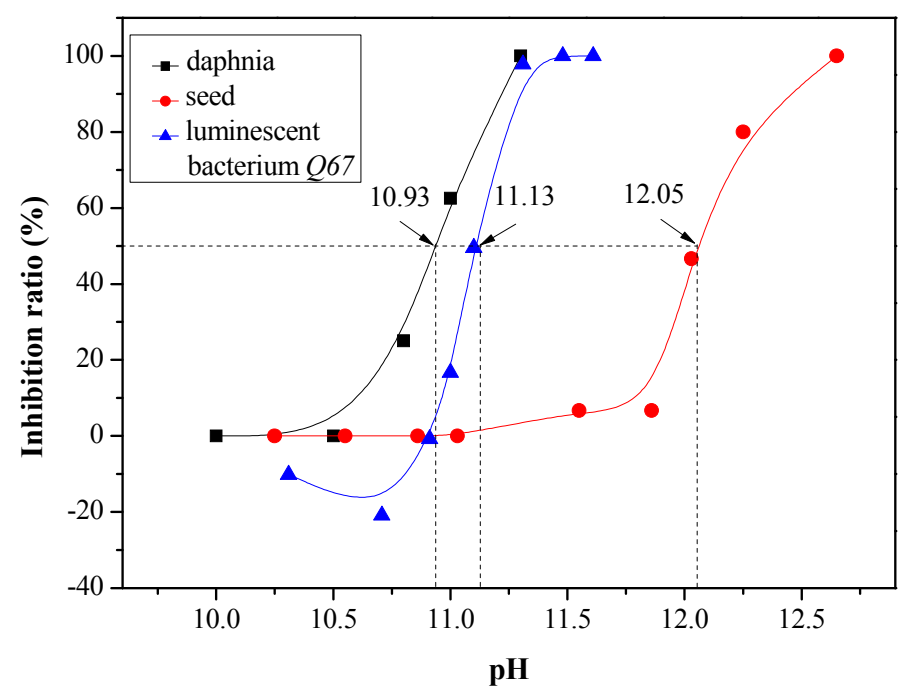

Figure 9. The impact of high $\mathrm{pH}$ values on the four tested organisms 